\title{
Lost Girls, Dead Poets, Last Waves
}

\author{
By Frank Cossa
}

Fall 1998 Issue of KINEMA

The Australian film director Peter Weir has created, over the last twenty years, a body of work of remarkable quality and consistency of vision. In virtually all of his films something -- often quite literally someone -gets lost. Innocence, idealism, and faith are the usual casualties. Moreover, there is nearly always a clash of cultures. His characters are thrown into a milieu they are not equipped to understand, one that seems hostile and threatening if only for its strangeness. In this, Weir is the quintessential Aussie; the perennial outsider. Australians are neither European, nor Asian, nor South Sea Islanders, yet they are all of these.

Picnic at Hanging Rock (1975) takes place on St. Valentine's Day, 1900, at a girls' school in Southeast Australia, a Victorian outpost on the edge of the bush. In the atmosphere of hothouse romanticism that pervades the place the girls exchange valentines and love notes. They are taken to a picnic at Hanging Rock, a volcanic formation on the slopes of Mount Macedon, sacred to the Aborigines. Three of the girls wander off, led by one named Miranda (Anne Lambert) whose resemblance to Botticelli's Venus makes her the darling of the school. They, and a Mathematics teacher who searches for them, disappear. One of the girls is found a week later but remembers nothing. The mystery is never solved.

Everyone's life is affected. The Headmistress, Mrs. Appleyard from Bournemouth (Rachel Roberts), the certainties of her Victorian world dissolving, sinks into an alcoholic oblivion. The school falls into financial ruin as parents withdraw their daughters. A young Englishman (Dominic Guard) searches obsessively for Miranda, though he only glimpsed her for a moment before she ascended the rock. A student infatuated with Miranda but not allowed to attend the picnic because her parents had not paid her fees, jumps from her window and falls through the roof of the greenhouse, dying among the flowers.

This ritual sacrifice of virgins to the dark forces of Nature happens in bright, buttery sunlight in an atmosphere of Proustian richness and density: "a l'ombre des jeunes filles en fleurs" (Milne). Shots of girls in white dresses dozing or the grass (photographed by Weir's frequent collaborator (Russell Boyd) resemble paintings by Renoir. Weir is more interested in atmosphere than explanations. The story comes from Joan Lindsay's 1967 novel; it has no basis in fact. Since the appearance of the film, however, the "incident" is believed to have occurred, and has entered popular folklore. Weir himself expressed some uneasiness as to whether an audience would accept this open-ended tale explained his intention "... to shift emphasis off the mystery element which had been building in the first half and to develop the oppressive atmosphere of something which has no solution: to bring out a tension and claustrophobia in the locations and the relationships... I did everything in my power to hypnotise the audience away from the possibility of solutions..." (Dawson, 83).

The Last Wave (1977) was actually the first of Weir's films to reach a wide audience. It established his reputation in America and opened the door for a generation of Australian filmmakers. Here an Anglo-Australian lawyer (Richard Chamberlain) becomes involved in the defence of some Aborigines and is recognised by them as the spiritual heir to an ancient (white) Australian race. He gains insight into their culture and learns to read their signs but is too late. The wave is coming.

The atmosphere in this film is as gloomy and wet as that of Picnic at Hanging Rock was bright and parched. The lawyer discovers dark, dripping caverns on the outskirts of the city where wall paintings tell of the coming catastrophe. We seem to be wandering with him in a melodramatic dreamtime where cause and effect hold even less sway than in Picnic.... It is the secretiveness of the Aboriginal culture, and the Anglos' fear of it, that gives the plot its mystery.

Australians share with most North-Americans the experience of being newcomers to the land they inhabit, and of being ignorant of the ancient cultures that gave the place its spiritual life. Weir claimed that he had "nothing to say about race relations" (Jacobs), but he cast a real spiritual leader (Nandjiwarra Amagula) in a pivotal role, and has the lawyer's wife, a fourth generation Australian, say that she has never met an Aborigine. 
Innocence is clearly the victim in Gallipoli (1981) as two young eastern Australian athletes, after getting lost in the desert in their own country, enlist to fight in "the war." The isolation of Australia is expressed succinctly by the old swagman who saves them in the desert and asks, "what war?" It is, of course, The Great War, and one of the lads feels some great mission to fight for his country, while the more sceptical one (Mel Gibson) seems to be along mostly for the ride.

The war turns out to have nothing to do with Australia. The country they are fighting for is Great Britain. Furthermore, they are sent by a cynical colonial government to a remote corner of the fray, Turkey, where the ANZACs are used as cannon fodder. The incompetence of their own officers completes the fiasco. As when they competed as sprinters the two heroes end by running. The Mel Gibson character is still not quite fast enough to deliver the message that will stop the slaughter, while his friend runs knowingly into the hail of bullets that ends his life, and the film in a memorable freeze frame. So ends the boys' adventure, in a pointless debacle, in a landscape as desolate as the one they left.

The Year of Living Dangerously (1982) is set in 1955 Indonesia where a naive, though ambitious, Aussie journalist named Guy Hamilton (Mel Gibson) arrives to cover the turmoil swirling around the Sukarno regime. He is introduced to the miserable conditions of the people of Jakarta by a Chinese Australian dwarf photographer, Billy Kwan (a brilliant turn by Linda Hunt, and a casting coup for Weir) who also introduces him to a British Embassy official named Jill Bryant (Sigourney Weaver). Sex happens, bullets fly, and the film is driven by what Andrew Sarris pithily called "A combination of chemistry, bone structure, and kinetic mise-en-scène."

The film could easily have turned into an old fashioned Hollywood adventure-romance were it not for the mesmerizing sequences of the Jakarta slums -- superbly photographed by Russell Boyd as a surreal nightmare at once beautiful and horrifying -- and the volatile political climate that envelopes the characters.

Billy chronicles the moral decline of his protégé; his falling in with cynical journalists, his casual professional ethics, his dangerous betrayal of confidences. Guy is too dense to grasp Billy's metaphor about Indonesian shadow puppets. He wants success and the girl in roughly that order and, roughly, gets both.

A number of critics have taken Weir to task for his political detachment. They wanted, no doubt, a grand if over-simplified gesture, for the director to show that his heart was in the right place. Rick putting Ilsa on the plane and walking off into the fog to win World War Two. These critics have seen too many movies. Sarris' complaint that Weir "... tends to confront the conscience of the west with the misery of the third world. But this argument is never developed into a dramatically coherent form that would integrate his characters with their milieu" is meant to be negative but sums up accurately Weir's reluctance to provide simple answers. This is not Rick's Casablanca. It is not commitment that these critics want but reassurance. What could be more arrogant, more detached from reality, than to believe that a westerner can walk into a third world country and instantly make a difference? We hardly needed to wait for Ethiopia, Haiti, or Rwanda, to learn that, for all our good intentions, we haven't got a clue.

There is a grand political gesture in The Year of Living Dangerously. For hanging an anti-Sukarno banner, which Sukarno never sees, Billy gives up his life. So much for grand gestures. Weir's position is clear enough. One may not agree with it but it is foolish to say that he hasn't got one. Indonesia is not France. Guy is not Rick. Leaving his tape recorder -- his westerner's version of The Story -- in the hands of a befuddled customs inspector, he gets on the plane with Jill.

In Witness (1984) Weir leaves his usual exotic locales for America, and weaves a complex set of variations on the themes of his earlier films. An Amish boy (Lucas Haas) named Samuel, travelling with his mother Rachel (Kelly McGillis) witnesses a brutal murder in a men's room in the Philadelphia train station. For the Amish -- a sect that broke with the Mennonites in 1697 because the Mennonites were not strict enough (Edelstein) -- Seeing is Participation. Merely to witness a corrupt act is to be corrupted. And it is through the lens-like eyes of Samuel that we witness the extraordinary events that follow.

A seasoned Philly detective, John Book (Harrison Ford), tries to protect the child and his mother from the killers, who turn out to be his colleagues, is wounded himself, and comes under the Amish's protection. Naturally they take him back to their farm in Lancaster County, Pennsylvania where the villains can't find them -- no telephones -- and Rachel can nurse him back to health. 
At first we laugh at the Amish, at their quaint ways, their puritanism. Soon, because Weir takes the time to develop it, we begin to witness life through their eyes. Book is awkward, funny, vulgar in this setting; ultimately, he is violent and dangerous. On a trip into town for supplies, their horse-and-buggy stopped in front of a Dairy Queen, the pacifist Amish are harassed by some local louts. Book, dressed like the Amish but not one of them, takes swift and violent action. This pointless and stupid act calls attention to his presence and endangers them all.

Inevitably the two worlds reach a tentative rapprochement. Rachel, a recent widow, is clearly smitten, and Book begins to soften. He gets up at 4:30 to milk the cows. He helps in a community "barn raisins." The camera shoots up -- a child's eye view -- at the men on the wooden structure, hammering, sweating, building a barn for a young family in a single day beneath a deep blue sky. The American pioneer experience has never been more exalted than in this justly celebrated set piece -- worthy of Howard Hawks or John Ford -aided by a rousingly Copland-esque music score by the French composer Maurice Jarre. Perhaps foreigners who grew up on American myths as seen in our films are able to approach them more freshly than we are. This scene could have been hopelessly mawkish if handled without the almost childlike belief that Weir brought to it.

The two cultures come together again when Book fixes an old car radio and begins to dance with Rachel to a Sam Cooke tune -- "Don't know much about History, don't know much Biology" - and for a moment two incompatible histories seem to be forgotten and biology about to take over. The scene has great charm but we are soon reminded that for the Amish this is a sin, one for which Rachel could be "shunned" by her people. There are no harmless pleasures in this society.

In the end violence begets violence. The bad cops arrive at the farm. Their car, their suits and ties, everything about them intrudes on the serenity of the landscape. Book is able to overcome them not with modern weapons like theirs but with arcane farm implements, tools that are now familiar to him but alien to them.

No Hollywood ending here. Book cannot remain an Amish farmer. He must return to the urban jungle where Rachel may not follow without violating her -- and her son's -- religious faith. She comes perilously close. She embraces him passionately, and lets him see her bathing once. But in the end tradition wins out, and we are glad of it. Two alien cultures have met and partly understood each other. We can hope for no more than that.

There followed three films which explored albeit somewhat tamely, variations on Weir's thematic obsessions. In The Mosquito Coast, from the novel by Paul Theroux, a genius inventor clings to the myth of self-reliance and rugged individualism in a debased Society. In the end that society as well as Nature, to which he tries to escape with his reluctant family, are both equally hostile environments. They combine to destroy him. Strong performances by Harrison Ford and Helen Mirren fail to rescue this film from its relentless pessimism.

In Dead Poets Society the conflict is between a free-spirit teacher and a conservative school in the late fifties. A group of too perfect male students are the battleground in this somewhat disappointing outing. The character of the teacher, played by Robin Williams, is abandoned after a few comic turns early on; he fails to live up to the values he preaches, and goes off meekly when he is held responsible for the melodramatic suicide of one of his students. There is an interesting inversion here, however, when the boys don hooded rain slickers and go off in the misty darkness like cowled monks to chant poetry in a cave and give themselves names like "Nwanda." They learn that one cannot truly understand Romanticism without becoming, however fleetingly, a Romantic. There is much unrealised potential here but one cannot be too hard on a director who makes an enormous popular success out of a film about curriculum.

In Green Card Weir's inevitable clash of cultures is not only the theme but the plot. Gerard Depardieu plays an illegal French alien, and Andie McDowell an ethereal southerner, just as out of place in New York as he is. They enter into a marriage of convenience based on Naturalization and Real Estate. Even as they rehearse the lies they will tell the Immigration Authorities they, naturally, fall in love. What looks to be a standard Hollywood romantic comedy is saved by an ironic turn. Now that they are telling the truth about their relationship they are not believed. Depardieu is deported.

With Fearless, Weir returned to form, and perhaps even exceeded his earlier standard. The film opens in a 
cornfield where Mexicans (aliens) are on their knees praying. Dazed people emerge from the yellow rows of corn: survivors of a plane crash. Among them is an architect, (Jeff Bridges) who begins to behave recklessly, constantly challenging death by balancing on ledges, crossing busy freeways, and eating strawberries to which he normally would have an allergic reaction. "They can't kill me!" he shouts. He has no use for the lawyer (Tom Hulce) or the therapist (John Turturro) who are trying to help him in the way that this society deems appropriate. What these well-meaning people fail to grasp is that he is now a member of a most exclusive culture: survivors of disaster. He even neglects his wife (Isabella Rossellini) in favour of a fellow survivor (Rosie Perez) who is consumed with guilt for failing to save her baby in the crash. He drives her around Oakland showing her the architecture but we see the buildings only as reflections in the windshield, upside down.

In one of the more stunning sequences in recent cinema, U2's "Where the Streets Have No Name" plays while the Bridges character drives his car, with Perez in the back seat, straight into a wall to prove to her that it was physically impossible to hold on to her baby during such an impact.

A climactic, if typically mysterious, redemption occurs when he eats a strawberry at home and appears to choke to death in his wife's arms. We then witness the harrowing plane crash from inside the plane to the lush sonorities of Gorecki's Symphony \#3. He survives, and is returned to mortality, to the life of which death must be a part.

Fearless extends Peter Weir's preoccupation with the outsider in an alien environment into the realm of philosophical enquiry. He poses the most essential questions of the Secular Humanist trying to wrench meaning and purpose from a way of life that offers only opportunism. Like his architect, who had a contract to design for "Nutty Nick," Weir has sometimes flitted with glossy success but there is every indication that he will continue to risk the narrow ledges and dangerous fruits of contemporary film making.

\section{Works Cited}

- Dawson, Jan. "Picnic Under Capricorn." Sight and Sound, Spring 1976, p. 83.

- Edelstein, David. "Witness." Village Voice, Feb. 12, 1995, p. 56.

- Jacobs, Diane. "Australian Originals." American Film, May 1973.

- Milne, Tom. "Picnic At Hanging Rock." Sight and Sound, Autumn 1976, p. 257.

- Sarris, Andrew. "The Year of Living Dangerously." Village Voice, Feb. 1, 1973, p. 59.

\section{Author Information}

Frank COSSA is Professor of Art History at the College of Charleston, South Carolina, where he teaches courses in film and photography. He has recently published articles on Stanley Kubrick and George Lucas. As a playwright, his works have been produced in New York and regional theatres in the US. 